\title{
Nicotinic acetylcholine receptors in human genetic disease
}

\author{
Christian P. Schaaf, MD, PhD ${ }^{1,2}$
}

Nicotinic acetylcholine receptors represent a family of ligand-gated ion channels that are widely expressed in the central and peripheral nervous systems. To date, 16 genes encoding subunits of mammalian nicotinic acetylcholine receptors have been identified. The various subunits form homomeric or heteromeric receptor proteins, allowing for a complex and adaptable system of nicotinic neurotransmission. Mutations of nicotinic receptor genes can cause Mendelian disorders, most importantly congenital myasthenic syndromes, multiple pterygium syndromes, and nocturnal frontal lobe epilepsies. Haploinsufficiency of CHRNA7 predisposes to neuropsy chiatric phenotypes in 15q13.3 deletion syndrome. The role of various nicotinic receptor genes is also discussed for complex disorders such as addiction, schizophrenia, Alzheimer disease, and Parkinson disease.

Genet Med advance online publication 20 February 2014

Key Words: acetylcholine; copy number variant; epilepsy; myasthenia; neuropsychiatric disease
Acetylcholine is an essential neurotransmitter in the central and peripheral nervous systems. Its signal can be transduced by two different types of receptors, which are classified by their sensitivity to either muscarine or nicotine. Muscarinic acetylcholine receptors are family-A G-protein-coupled receptors, whereas nicotinic acetylcholine receptors are ligand-gated ion channels. ${ }^{1,2}$ Muscarinic receptors are widely recognized for their role in the parasympathetic nervous system. Their signals are relatively slow and evolve over seconds to minutes. Nicotinic receptors, on the other hand, mediate fast synaptic transmission in millisecond time frames. They are critical to development and synaptic plasticity, and they participate in learning, memory, and attention. The major cholinergic nuclei of the mammalian brain are located in the basal forebrain, from which they project throughout the cortex and the hippocampus. Cholinergic nuclei of the brain stem, in particular the pedunculopontine nucleus and the laterodorsal tegmental nucleus, provide widespread innervation to the thalamus and the midbrain. Cholinergic interneurons control excitatory input in the striatum, and they are important terminal zones of dense dopaminergic projections in the nucleus accumbens. ${ }^{2,3}$ Acetylcholine is released into the synaptic cleft, but also at nonsynaptic sites. Activation of presynaptic nicotinic receptors causes enhanced neurotransmitter release, whereas postsynaptic nicotinic acetylcholine receptors contribute to fast excitatory transmission. Nonsynaptic nicotinic acetylcholine receptors contribute to diffuse volume transmission, thereby influencing neuronal excitability and modulating various neurotransmitter systems. ${ }^{2}$ Release of acetylcholine is episodic and in a pulsed manner. Depending on presence, abundance, and timing of acetylcholine binding, nicotinic acetylcholine receptors can adopt one of three functional states: closed at rest, open pore, and closed desensitized. ${ }^{2}$ Prolonged exposure to low doses of acetylcholine, nicotine, or a nicotinic agonist will cause significant desensitization, which stabilizes the receptor in the closed state, unresponsive to further agonist stimulation. ${ }^{4}$ This needs to be considered when discussing therapeutic interventions in disorders of nicotinic acetylcholine receptors.

Nicotinic acetylcholine receptors are assembled from five transmembrane subunits, which are arranged around a central water-filled pore. To date, 16 distinct subunits of nicotinic acetylcholine receptors have been identified in the human proteome, of which 11 are neuronal $(\alpha 2-7, \alpha 9, \alpha 10, \beta 2-4)$ and 5 are muscular $(\alpha 1, \beta 1, \gamma, \delta$, and $\varepsilon)$. The respective human genes are CHRNA1-7, CHRNA9, CHRNA10, CHRNB1-4, CHRNG, CHRND, and CHRNE. There are two subtypes of the muscular nicotinic acetylcholine receptor: $(\alpha 1)_{2} \beta 1 \delta \gamma$, which represents the fetal form, and $(\alpha 1)_{2} \beta 1 \delta \varepsilon$, which represents the adult form. During development, the former is gradually replaced by the latter. Therefore, mutations in CHRNG cause phenotypes of congenital manifestation, whereas mutations in CHRNE manifest postnatally. The diversity of nicotinic acetylcholine receptors in the human brain is significant, due to the combinatorial effects of subunit assembly in heteropentameric receptors. Several different subtypes can be expressed within the same tissue or even within the same cell. Only two subunits ( $\alpha 7$ and $\alpha 9)$ are known to form homopentameric nicotinic acetylcholine receptors, of which only $\alpha 7$ is abundantly expressed and distributed in the human brain. Neuronal heteropentamers are formed by two $\alpha$ units $(\alpha 2-6)$ and three $\beta$ units ( $\beta 2-4)$. Heteropentameric receptors have two acetylcholine-binding sites, which are located between the $\alpha$ and $\beta$ subunits each. 
Homopentameric receptors have five binding sites, one at each interface between two subunits. ${ }^{2,5}$

To date, 9 of the 16 human nicotinic acetylcholine receptor genes have been associated with Mendelian disorders. An overview is provided in Table 1 .

\section{CONGENITAL MYASTHENIC SYNDROMES}

Congenital myasthenic syndromes (CMSs) are a group of genetically determined disorders characterized by dysfunction of neuromuscular transmission, clinically manifesting as muscular weakness that worsens with exertion, and strength returning

Table 1 Monogenic disorders of human nicotinic acetylcholine receptor genes

\begin{tabular}{|c|c|c|c|c|c|c|}
\hline Gene & Location $^{\text {a }}$ & $\begin{array}{l}\text { Mendelian } \\
\text { disorder(s) }\end{array}$ & $\begin{array}{l}\text { Inheritance } \\
\text { pattern }\end{array}$ & $\begin{array}{l}\text { Mutation } \\
\text { type(s) }\end{array}$ & $\begin{array}{l}\text { (Proposed) } \\
\text { mechanism }\end{array}$ & Reference(s) \\
\hline \multirow[t]{4}{*}{ CHRNA1 } & $2 q 31.1$ & $\begin{array}{l}\text { Congenital myasthenic syndrome } \\
\text { (slow-channel), OMIM } 601462\end{array}$ & $\begin{array}{l}\text { Autosomal } \\
\text { dominant }\end{array}$ & Missense & Gain of function & $40-43$ \\
\hline & & $\begin{array}{l}\text { Congenital myasthenic syndrome } \\
\text { (fast-channel), OMIM } 608930\end{array}$ & $\begin{array}{l}\text { Autosomal } \\
\text { recessive }\end{array}$ & Missense & Loss of function & $44-46$ \\
\hline & & & $\begin{array}{l}\text { Autosomal } \\
\text { dominant }\end{array}$ & Missense & Loss of function & 47 \\
\hline & & $\begin{array}{l}\text { Lethal multiple pterygium } \\
\text { syndrome, OMIM } 253290\end{array}$ & $\begin{array}{l}\text { Autosomal } \\
\text { recessive }\end{array}$ & Nonsense & Loss of function & 48 \\
\hline CHRNA2 & $8 p 21.2$ & $\begin{array}{l}\text { Nocturnal frontal lobe epilepsy, } \\
\text { type } 4, \text { OMIM } 610353\end{array}$ & $\begin{array}{l}\text { Autosomal } \\
\text { dominant }\end{array}$ & Missense & Gain of function & 49 \\
\hline CHRNA3 & $15 q 25.1$ & None & N/A & N/A & N/A & N/A \\
\hline CHRNA4 & $20 q 13.33$ & $\begin{array}{l}\text { Autosomal dominant nocturnal } \\
\text { frontal lobe epilepsy, type } 1, \\
\text { OMIM } 600513\end{array}$ & $\begin{array}{l}\text { Autosomal } \\
\text { dominant }\end{array}$ & Missense, indel & $\begin{array}{l}\text { Gain of function, } \\
\text { loss of function }\end{array}$ & $50-52$ \\
\hline CHRNA5 & $15 q 25.1$ & None & N/A & N/A & N/A & N/A \\
\hline CHRNA6 & $8 p 11.21$ & None & N/A & $\mathrm{N} / \mathrm{A}$ & $\mathrm{N} / \mathrm{A}$ & $\mathrm{N} / \mathrm{A}$ \\
\hline CHRNA7 & $15 q 13.3$ & $\begin{array}{l}15 q 13.3 \text { microdeletion syndrome, } \\
\text { OMIM } 612001\end{array}$ & $\begin{array}{l}\text { Autosomal } \\
\text { dominant } \\
\text { (semidominant) }\end{array}$ & $\begin{array}{l}\text { Whole-gene } \\
\text { deletion }\end{array}$ & Haploinsufficiency & $15-18,22,24$ \\
\hline CHRNA9 & $4 p 14$ & None & N/A & N/A & N/A & N/A \\
\hline CHRNA10 & $11 \mathrm{p} 15.4$ & None & N/A & N/A & N/A & N/A \\
\hline \multirow[t]{2}{*}{ CHRNB1 } & 17p13.1 & $\begin{array}{l}\text { Congenital myasthenic syndrome } \\
\text { (slow-channel), OMIM } 601462\end{array}$ & $\begin{array}{l}\text { Autosomal } \\
\text { dominant }\end{array}$ & Missense & Gain of function & 40,53 \\
\hline & & $\begin{array}{l}\text { Congenital myasthenic syndrome } \\
\text { associated with acetylcholine } \\
\text { receptor deficiency, OMIM } 608931\end{array}$ & $\begin{array}{l}\text { Autosomal } \\
\text { recessive }\end{array}$ & Indel, exon skipping & Loss of function & 54 \\
\hline CHRNB2 & $1 \mathrm{q} 21.3$ & $\begin{array}{l}\text { Nocturnal frontal lobe epilepsy, } \\
\text { type 3, OMIM } 605375\end{array}$ & $\begin{array}{l}\text { Autosomal } \\
\text { dominant }\end{array}$ & Missense & Gain of function & 55,56 \\
\hline CHRNB3 & $8 p 11.21$ & None & N/A & N/A & N/A & N/A \\
\hline CHRNB4 & $15 q 25.1$ & None & N/A & N/A & N/A & N/A \\
\hline \multirow[t]{3}{*}{ CHRND } & $2 q 37.1$ & $\begin{array}{l}\text { Lethal multiple pterygium } \\
\text { syndrome, OMIM } 253290\end{array}$ & $\begin{array}{l}\text { Autosomal } \\
\text { recessive }\end{array}$ & Nonsense, missense & Loss of function & 48 \\
\hline & & $\begin{array}{l}\text { Congenital myasthenic syndrome } \\
\text { (fast-channel), OMIM } 608930\end{array}$ & $\begin{array}{l}\text { Autosomal } \\
\text { recessive }\end{array}$ & Missense, indel & Loss of function & 45,57 \\
\hline & & $\begin{array}{l}\text { Congenital myasthenic syndrome } \\
\text { (slow-channel), OMIM } 601462\end{array}$ & $\begin{array}{l}\text { Autosomal } \\
\text { dominant }\end{array}$ & Missense & Gain of function & 58 \\
\hline \multirow[t]{4}{*}{ CHRNE } & $17 p 13.2$ & $\begin{array}{l}\text { Congenital myasthenic syndrome } \\
\text { associated with acetylcholine } \\
\text { receptor deficiency, OMIM } 608931\end{array}$ & $\begin{array}{l}\text { Autosomal } \\
\text { recessive }\end{array}$ & $\begin{array}{l}\text { Nonsense, missense, } \\
\text { indel, splice site, } \\
\text { promoter }\end{array}$ & Loss of function & $40,59-66$ \\
\hline & & $\begin{array}{l}\text { Congenital myasthenic syndrome } \\
\text { (fast-channel), OMIM } 608930\end{array}$ & $\begin{array}{l}\text { Autosomal } \\
\text { recessive }\end{array}$ & Missense & Loss of function & $67-70$ \\
\hline & & $\begin{array}{l}\text { Congenital myasthenic syndrome } \\
\text { (slow-channel), OMIM } 601462\end{array}$ & $\begin{array}{l}\text { Autosomal } \\
\text { dominant }\end{array}$ & Missense & Gain of function & $40,67,71,72$ \\
\hline & & $\begin{array}{l}\text { Congenital myasthenic syndrome } \\
\text { (slow-channel), OMIM } 601462\end{array}$ & $\begin{array}{l}\text { Autosomal } \\
\text { recessive }\end{array}$ & Indel, missense & Uncertain & 72 \\
\hline \multirow[t]{2}{*}{ CHRNG } & $2 q 37.1$ & Escobar syndrome, OMIM 265000 & $\begin{array}{l}\text { Autosomal } \\
\text { recessive }\end{array}$ & $\begin{array}{l}\text { Missense, indel, } \\
\text { nonsense }\end{array}$ & Loss of function & 73,74 \\
\hline & & $\begin{array}{l}\text { Lethal multiple pterygium } \\
\text { syndrome, OMIM } 253290\end{array}$ & $\begin{array}{l}\text { Autosomal } \\
\text { recessive }\end{array}$ & Exon deletion, indel & Loss of function & 74 \\
\hline
\end{tabular}


(at least partially) after resting. ${ }^{6}$ Depending on the localization of the mutated protein, CMSs are classified into four categories: (i) presynaptic compartment CMS, (ii) synaptic basal laminaassociated CMS, (iii) postsynaptic compartment CMS, and (iv) CMS caused by deficient protein glycosylation. Postsynaptic disorders can be divided into two kinetic defects, fast-channel (OMIM 608930) and slow-channel (OMIM 601462) CMSs, and a third disorder, CMS with acetylcholine receptor deficiency (OMIM 608931). Mutations in genes encoding nicotinic acetylcholine receptors (CHRNA1, CHRNB1, CHRND, and CHRNE) are considered postsynaptic compartment CMSs and are responsible for up to $60 \%$ of all cases (Table 1). ${ }^{7}$ Deficient clustering of acetylcholine receptors at the end plate can be caused by mutations in MUSK, RAPSN, or DOK7, and others, causing CMSs with acetylcholine receptor deficiency and abnormal synaptic differentiation. ${ }^{7}$ The single most common gene causing CMS is CHRNE, accounting for $20-25 \%$ of all cases, and $50 \%$ of those in which a molecular diagnosis can be established. ${ }^{7}$ In slowchannel CMSs, gain-of-function mutations cause prolonged activations of the nicotinic acetylcholine receptors. These usually follow autosomal dominant inheritance. Treatment consists of long-acting open-channel blockers fluoxetine and quinidine; however, the efficacy and tolerability features of these medications are limited. ${ }^{6}$ In fast-channel CMSs, receptor activations are brief because acetylcholine receptors do not stay open long enough. These are usually caused by loss-of-function mutations and follow autosomal recessive inheritance. Fast-channel CMS is treated with acetylcholine esterase inhibitors and 3,4-diaminopyridine. ${ }^{6}$ The most common type of CMS, i.e., CMS associated with acetylcholine receptor deficiency, may or may not have minor kinetic abnormalities. The causative mutations involve loss of function, and the inheritance pattern is autosomal recessive. The affected individuals respond favorably, but incompletely, to acetylcholine esterase inhibitors. Additional use of 3,4-diaminopyridine may result in further improvement, in particular by increasing endurance. ${ }^{8}$

\section{MULTIPLE PTERYGIUM SYNDROMES}

Multiple pterygium syndromes are a group of disorders clinically characterized by the presence of joint contractures (arthrogryposis) and pterygia (skin webbing across joints, e.g., neck, elbows, knees), frequently accompanied by additional congenital anomalies. ${ }^{9}$ Loss-of-function mutations in the muscular nicotinic acetylcholine receptor genes CHRNA1, CHRND, and $C H R N G$ have been identified as the causes of multiple pterygium syndromes, following recessive inheritance (Table 1). One could conceive that homozygous or compound heterozygous mutations in CHRNB1 may cause multiple pterygium syndrome, but no such case has been reported in the literature to date. Mutations in CHRNE, which is only expressed in the late fetal, perinatal, and postnatal periods, would not be expected to cause a severe congenital phenotype such as that seen in multiple pterygium syndromes.

Lethal (OMIM 25390) and nonlethal (OMIM 265000, Escobar variant) forms of multiple pterygium syndromes exist. Mutations in CHRNA1, CHRND, and CHRNG have been reported as the causes of the lethal type. On the other hand, mutations of CHRNG are the only known cause of the nonlethal Escobar variant to date. The phenotype of Escobar syndrome is caused by the transient inactivation of the neuromuscular end plate, quite similar to the symptoms found in neonates with congenital arthrogryposis who were exposed to maternal acetylcholine receptor antibodies during fetal development. Because CHRNG gene expression is restricted to early development (before the 33rd week of gestation in humans), patients with Escobar syndrome do not manifest myasthenic symptoms later in life, which is a major difference from disorders caused by mutations in other acetylcholine receptor subunits. The treatment of Escobar syndrome is symptomatic. Early surgical intervention is recommended to prevent progression of deformity and a decrease in pulmonary capacity, especially if scoliosis is severe. Orthopedic therapy with splinting combined with vigorous physical therapy is critical, to increase joint mobility and to decrease muscle atrophy.

\section{AUTOSOMAL DOMINANT NOCTURNAL FRONTAL LOBE EPILEPSY}

Nocturnal frontal lobe epilepsies (OMIM 600513, OMIM 605375, OMIM 610353, and OMIM 615005) are a group of idiopathic partial epilepsies characterized by clustered attacks of brief motor seizures, mostly occurring during non-rapid eye movement sleep..$^{10}$ The age of onset is usually during childhood or adolescence, although this may vary considerably, even within the same family. The motor manifestations are often stereotyped and consist of brief stiffening of the limbs, accompanied by dystonic movements of neck, arms, and legs. Grunting sounds, vocalizations, and difficulty in breathing can occur with the seizures, and sleepwalking has been reported. Parasomnias, which are nonepileptic events with similar clinical presentation, are the most important differential diagnosis. Mean seizure frequency in autosomal dominant nocturnal frontal lobe epilepsy is about 20 per month. More than $90 \%$ of nocturnal frontal lobe seizures arise during sleep, and although about one-third of patients with nocturnal frontal lobe epilepsy may have seizures during the awake state, these are rare (less than 10 per year) and are usually confined to childhood and adolescence.

Mutations in CHRNA2, CHRNA4, and CHRNB2 have been found to cause autosomal dominant nocturnal frontal lobe epilepsy (Table 1). All mutations reported to date are missense mutations or indels (insertions/deletions) and usually affect the transmembrane domains or very nearby domains of the respective proteins, thereby affecting the kinetics of the ion pore. Mutations in CHRNA2 and CHRNB2 are usually gain-of-function mutations, leading to increased sensitivity to acetylcholine or retardation of desensitization of the receptor. For CHRNA4, mutations can either be either gain-of-function (increased affinity to acetylcholine) or loss-of-function (acceleration of desensitization and decreased calcium permeability) types. ${ }^{10}$ Mutations in one non-nicotinic receptor gene, KCNT1, 
have been found to be a cause of severe autosomal dominant nocturnal frontal lobe epilepsy with behavioral or psychiatric problems and intellectual disability. ${ }^{11}$

Inheritance of all nocturnal frontal lobe epilepsies is autosomal dominant, and the estimated penetrance is high (70$80 \%)$, however with variable clinical expressivity. Some of the reported mutations not only cause epilepsy but also can be associated with additional neurological and psychiatric features. Examples are the p.259insL mutation in CHRNA4, which not only causes nocturnal seizures, but also psychiatric disease, in particular schizophrenia, and the p.I312M mutation in CHRNB2, which not only causes seizures but also distinct cognitive impairments. ${ }^{5}$

The seizures of nocturnal frontal lobe epilepsy are usually relatively benign, as they occur during sleep and, in most cases, respond very well to treatment with antiepileptic medications. Carbamazepine has been shown to be efficacious in about two-thirds of cases, greatly reducing seizure frequency and complexity. A single dose at bedtime is usually sufficient. Other reported treatments of nocturnal frontal lobe epilepsy include topiramate, oxcarbazepine, and transdermal nicotine patch. ${ }^{10}$ About $30 \%$ of cases with nocturnal frontal lobe epilepsy are resistant to antiepileptic drugs. Surgical intervention might have an indication in these nonresponders. Whether there are specific genotypes causing nonresponsiveness to treatment in nocturnal frontal lobe epilepsy remains unclear at this time.

\section{NEUROPSYCHIATRIC PHENOTYPES AND COPY NUMBER VARIATIONS OF CHRNA7}

The $\alpha 7$ subunit is unique in that it forms functional homopentameric receptors that are abundantly expressed in the human brain. Structurally, $\alpha 7$ is thought to be the closest to the most ancient forms of nicotinic receptors that evolved millions of years ago and seems to have preserved specific functionalities, such as high calcium permeability and certain toxin sensitivity (e.g., $\alpha$-bungarotoxin). ${ }^{12}$ The human CHRNA7 gene is located on chromosome 15q13.3, in one of the most unstable regions of the human genome. Proximal 15q (15q11-q14) is rich in low-copy repeats. DNA copy number variations of the region include deletions, pericentric and paracentric inversions, duplications, triplications, translocations, and supernumerary inv dup(15) chromosomes. ${ }^{13}$ Break points of these rearrangements are located within complex sets of low-copy repeats named break point 1 (BP1) to BP6. The CHRNA7 gene is located between BP4 and BP5, which have been proposed to mediate most of the rearrangements involving CHRNA7. They are constituted by a complex set of large duplicated segments with $>99 \%$ identity, positioned in opposite directions relative to each other. A paracentric inversion between BP4 and BP5 is frequently found in various populations. A small inversion within a portion of BP4 has been postulated to put segments of BP4 and BP5 in direct orientation relative to each other, which, in turn, can predispose to nonallelic homologous recombination, resulting in recurrent reciprocal BP4-BP5 microdeletions and microduplications. Additional, smaller low-copy repeats within the BP4-BP5 segment play a role in the etiology of smaller copy number variants involving the CHRNA7 gene. In fact, at least six different classes of microduplications, varying in size from $350 \mathrm{~kb}$ to $1.6 \mathrm{Mb}$, have been shown to arise involving preexisting heterogeneous inverted BP4-BP5 chromosomes. ${ }^{13}$

Chromosome 15q13.2 also harbors the chimeric CHRFAM7A gene, which is a partial duplication of CHRNA7 (exons 5-10) forming a hybrid with a novel gene from the family with sequence similarity 7 (FAM7A). The FAM7A part consists of four exons (named D, C, B, and A), of which three $(\mathrm{C}, \mathrm{B}, \mathrm{A})$ arose from a partial duplication of ULK4 (a serine/threonine kinase on chromosome 3p22) and one (D) is of unknown provenance. The CHRFAM7A gene is human specific and is located on $15 \mathrm{q} 13.2$, only $1.6 \mathrm{Mb}$ centromeric to CHRNA7, transcribed in opposite direction. It is expressed in multiple tissues, including brain, although less abundantly than CHRNA7. Copy number of CHRFAM7A is highly variable in humans. Although most individuals have one or two copies of CHRFAM7A, some have zero and some have three copies. The CHRFAM7A protein has been proposed to be a dominant negative regulator of the $\alpha 7$ nicotinic acetylcholine receptor. ${ }^{14}$

\section{CHRNA7 deletions}

Heterozygous microdeletions between BP4 and BP5 on chromosome 15q13.2q13.3 including CHRNA7 (OMIM 612001) were first reported in 2008 as a cause of intellectual disability and seizures ${ }^{15-18}$ and then were also found to be overrepresented in cohorts of individuals with schizophrenia. ${ }^{19,20}$ The deletion is found in $\sim 1 \%$ of individuals with idiopathic generalized epilepsy. ${ }^{21}$ These deletions affect a total of six genes in the National Center for Biotechnology Information's Reference Sequence database (RefSeq)-MTMR15, MTMR10, TRPM1, KLF13, OTUD7A, and CHRNA7-as well as a microRNA gene, hsamir211. Based on expression patterns and function, haploinsufficiency of CHRNA7 had been considered the probable cause of BP4-BP5 deletion syndrome, which was then substantiated by the identification of individuals with much smaller deletions affecting only CHRNA7 and the first exon of a noncoding RNA variant of OTUD7A. ${ }^{22}$ The affected individuals manifest phenotypes highly similar to those seen in BP4-BP5 deletion syndrome, i.e., developmental delay, intellectual disability, and seizures. Deletions including CHRNA7 are not found in control cohorts and therefore appear to have complete penetrance. ${ }^{23}$ This is only questioned by a few reports of individuals with rare homozygous or compound heterozygous deletions involving CHRNA7, for whom parents heterozygous for the deletion are reported as healthy with normal intelligence and no history of psychiatric disorder. ${ }^{24}$ One might conclude that the penetrance for neuropsychiatric phenotypes in individuals with deletion of CHRNA7 is high, but not quite $100 \%$. Homozygous or compound heterozygous deletions of CHRNA7 cause a phenotype of neonatal encephalopathy, with severe hypotonia, cortical visual impairment, profound developmental and intellectual impairment, and intractable epilepsy. ${ }^{24-26}$ 


\section{CHRNA7 duplications}

Duplications reciprocal to the BP4-BP5 deletions were first described by van Bon ${ }^{18}$; however, due to the small number of patients reported, it was difficult to conclude whether this microduplication actually contributes to the etiology of neurodevelopmental phenotypes. Szafranski et al. ${ }^{13}$ then reported four additional BP4-BP5 duplication cases and 55 smaller CHRNA7 duplications that had been identified by clinical chromosome microarray analysis. They went on to describe two different classes of BP4-BP5 duplications and five classes of small CHRNA7 duplications, based on size differences and break points. Clinical data were available for 11 probands and their families and suggested an overrepresentation of developmental delay/intellectual disability, muscular hypotonia, and a variety of neuropsychiatric disorders among the affected individuals. However, it was noticed that the small CHRNA7 duplications are seen at high frequency not only among affected individuals, but also in control cohorts, so it was concluded that the clinical significance of these microduplications was uncertain. ${ }^{13}$ In fact, there are at least five studies published to date that tested the prevalence of CHRNA7 duplications in control populations, ${ }^{21,27-30}$ with a total prevalence of 134 CHRNA7 duplications in 24,980 individuals (for a frequency of 1 in 186). The prevalence of small CHRNA7 duplications among all samples submitted for clinical chromosome microarray analysis is 185 in 32,212 ( 1 in 174), ${ }^{13,27}$ which is not a difference of statistical significance when compared with the prevalence among controls (one-tailed $P$ value of 0.2922 in a $\chi^{2}$ test with Yates correction). Significant enrichment of the small CHRNA7 duplications was, however, shown among individuals with attention deficit hyperactivity disorder, with an odds ratio of 2.22 (a total of 34 individuals with CHRNA7 duplication among 3,003 individuals total, for a frequency of 1 in 88). ${ }^{28}$ In summary, based on current data, the role and significance of CHRNA7 duplications in the etiology of neuropsychiatric disease is limited. It has not yet been determined whether duplication of CHRNA7 causes actual overexpression of the $\alpha 7$ nicotinic acetylcholine receptor, in particular in human brain. No studies have investigated whether CHRNA7 duplication changes the electrophysiology, connectivity, or function of the human brain. One might speculate that copy number of CHRFAM7A could have a modifying effect, such that an increasing copy number of CHRFAM7A decreases the effect of increasing copy number of CHRNA7. The high frequency of CHRNA7 duplications in the general population would make them a common risk factor for behavioral and neuropsychiatric phenotypes should there be enough evidence for a true pathological effect.

\section{COMPLEX DISORDERS}

The involvement of nicotinic acetylcholine receptors is being discussed in several other disorders, mostly common disorders of complex inheritance and multifactorial etiology. Four (groups of) disorders worth discussing are schizophrenia, addiction, Alzheimer disease, and Parkinson disease.

\section{Schizophrenia}

It is well known that individuals with schizophrenia have a much higher prevalence of smoking (90\%) when compared with the general population (33\%). ${ }^{31}$ Individuals with schizophrenia have a small, but significant and reproducible, decrease in ${ }^{125}$ I- $\alpha$-bungarotoxin-binding sites and $\alpha 7$ immunoreactivity in the hippocampus, reticular nucleus of the thalamus, and the cingulate and frontal cortex. ${ }^{31}$ In addition, sensory gating by p50 auditory evoked potentials is deficient among many individuals with schizophrenia and has been mapped to $15 \mathrm{q} 13-14$ by linkage, the locus that contains the CHRNA7 gene. ${ }^{32}$ Polymorphisms in the promoter of CHRNA7 have been associated with schizophrenia and diminished p50 sensory gating. ${ }^{33,34}$ Nicotine has been shown to transiently reverse p50 deficits, ${ }^{32}$ and, more importantly, a selective $\alpha 7$ partial agonist, EVP-6124, has been shown to have clinically meaningful effects on global cognitive function, negative symptoms, and general clinical function in individuals with schizophrenia. ${ }^{35}$

\section{Addiction}

The addictive effects of nicotine are at least in part mediated via $\alpha 4 \beta 2$-containing nicotinic acetylcholine receptors, which cause increases in mesolimbic dopamine release leading to nicotine dependence. ${ }^{12}$ In addition, nicotinic acetylcholine receptors can modulate the release of many other neurotransmitters and mediate the neuronal mechanisms associated with development and maintenance of drug addiction. There is high comorbidity of nicotine and alcohol dependence, which at least in part is explained by common underlying cholinergic mechanisms. In particular, the CHRNA5/A3/B4 cluster on chromosome 15q25.1 has been associated with both nicotine and alcohol dependence. For other drug dependencies data are much more limited, and although the cholinergic system has been shown to play a role in several aspects of cocaine dependence in various animal studies, there is a relative lack of human data, and the contributions of specific nicotinic receptors are yet to be elucidated. ${ }^{12}$

\section{Alzheimer disease}

The most well-appreciated loss of neurons in brains of people with Alzheimer disease is that of the cholinergic system, in particular the basal forebrain cholinergic neurons. ${ }^{36}$ The decline of cortical cholinergic activity correlates with the severity of Alzheimer symptoms and intellectual deterioration. Along with clinical progression, the number of nicotinic acetylcholine receptors decreases, especially in the hippocampus and cortex. ${ }^{37}$ In addition, a role for $\alpha 4$ and $\alpha 7$ has been suggested in the accumulation of $\beta$ amyloid peptide and hyperphosphorylated tau. ${ }^{38}$ The most commonly prescribed drugs for Alzheimer disease are acetylcholine esterase inhibitors. But nicotinic agonist agents also are increasingly shown to improve cognitive deficits in Alzheimer disease patients. ${ }^{12}$

\section{Parkinson disease}

The motor symptoms of Parkinson disease result from a degeneration of dopaminergic neurons in the nigrostriatal pathway. 
Nicotinic acetylcholine receptors are important in promoting the release of dopamine in this pathway, in particular $\alpha 6 \beta 3 \beta 2$ and $\alpha 4 \beta 2$ receptors, which facilitate the release of dopamine from nerve endings in the striatum. ${ }^{31} \mathrm{~A}$ decrease of nicotinic acetylcholine receptors has been found in the cerebral cortex of Parkinson disease patients and is mainly attributed to a decrease in $\alpha 4$ - and $\alpha 7$-containing receptors. Finally, epidemiological studies show that smoking is associated with a lower incidence of Parkinson disease. ${ }^{39}$ Not surprisingly, nicotine and nicotinic receptor agonists are being investigated as promising therapeutic agents in the management of Parkinson disease. ${ }^{12}$

\section{THERAPEUTIC CONSIDERATIONS}

As outlined in some of the above sections, disorders of nicotinic acetylcholine receptors have promising therapeutic potential that goes well beyond symptomatic treatment but exploits a more fundamental understanding of disease mechanisms and neuropharmacology. Nicotinic agonist drugs are currently approved and marketed for smoking cessation and in advanced clinical trials for depression, attention deficit hyperactivity disorder, schizophrenia, Alzheimer disease, and Parkinson disease. ${ }^{12}$ With dramatic advances in our understanding of the exact genetic causes of disorders of nicotinic acetylcholine receptors, along with increasing knowledge of what the respective genetic mutations and alterations do on a (patho)physiological level, there is hope that rational molecular therapies are actually within reach. The interest of the pharmacological industry in common disorders such as Alzheimer disease, Parkinson disease, and nicotine addiction will also prove to be beneficial for the much more rare orphan diseases caused by deficient nicotinic signaling.

The promiscuity of the nicotinic acetylcholine receptor system represents a major challenge to the development of respective compounds. Many have failed in clinical trials, either due to lack of efficacy or due to side effects, resulting in unacceptably narrow therapeutic windows. There is great need for drugs that have an optimal combination of pharmacodynamics (potency and selectivity) and pharmacokinetics (absorption, penetration across the blood-brain barrier, and protein binding) to preferentially target a given nicotinic acetylcholine receptor subtype with doses that would be inefficient at other receptor subtypes, to minimize side effects. ${ }^{12}$ Beyond nicotinic agonists, positive allosteric modulators are getting increasing attention because they lack the intrinsic activity and only become active in the presence of acetylcholine, causing a potentiation of its effect. Allosteric binding sites are topographically distinct from agonist binding sites, are less conserved, and differ among nicotinic receptor subtypes, so that selectivity for positive allosteric modulators can be achieved much more easily than for cholinergic agonist drugs. Combination strategies of agonists plus positive allosteric modulators may be particularly attractive whenever a decreased number of functional receptors is present because some positive allosteric modulators may oppose agonist-induced desensitization. ${ }^{2,12}$
In summary, the importance of nicotinic acetylcholine receptors is increasingly recognized in the field of neurological, behavioral, psychiatric, and neurodegenerative disorders. There is tremendous potential for the development and implementation of targeted therapies for both the rare, monogenic Mendelian disorders of nicotinic acetylcholine receptor genes, and the more common, genetically complex diseases manifesting decreased cholinergic signaling.

\section{ACKNOWLEDGMENTS}

C.P.S. is generously supported by the Joan and Stanford Alexander Family. He is a recipient of a Clinical Scientist Development Award by the Doris Duke Charitable Foundation. The author thanks his mentors, Huda Zoghbi and Arthur Beaudet, for their guidance and generous support. Jill Rosenfeld is acknowledged for discussion and input regarding copy number variation of CHRNA7. The author expresses his sincere gratitude to the William K. Bowes, Jr. Award Committee for their generosity, recognition, and promotion of medical genetics.

\section{DISCLOSURE}

C.P.S. is a faculty member of the Department of Molecular and Human Genetics at Baylor College of Medicine, which derives revenue from genetic testing offered in the Medical Genetics Laboratory.

\section{REFERENCES}

1. Ishii M, Kurachi Y. Muscarinic acetylcholine receptors. Curr Pharm Des 2006;12:3573-3581.

2. Dani JA, Bertrand D. Nicotinic acetylcholine receptors and nicotinic cholinergic mechanisms of the central nervous system. Annu Rev Pharmacol Toxicol 2007;47:699-729.

3. Deutsch SI, Schwartz BL, Urbano MR, Burket JA, Benson AD, Herndon AL. Nicotinic acetylcholine receptors in autism spectrum disorders: therapeutic implications. Comprehensive Guide to Autism. Springer: New York, NY, 2014:755-777.

4. Giniatullin R, Nistri A, Yakel JL. Desensitization of nicotinic ACh receptors: shaping cholinergic signaling. Trends Neurosci 2005;28:371-378.

5. Steinlein OK, Bertrand D. Neuronal nicotinic acetylcholine receptors: from the genetic analysis to neurological diseases. Biochem Pharmacol 2008;76:11751183

6. Hantaï D, Nicole S, Eymard B. Congenital myasthenic syndromes: an update. Curr Opin Neurol 2013;26:561-568.

7. Abicht A, Dusl M, Gallenmüller C, et al. Congenital myasthenic syndromes: achievements and limitations of phenotype-guided gene-after-gene sequencing in diagnostic practice: a study of 680 patients. Hum Mutat 2012;33:1474-1484

8. Engel AG. The therapy of congenital myasthenic syndromes. Neurotherapeutics 2007:4:252-257.

9. Vogt J, Morgan NV, Rehal P, et al. CHRNG genotype-phenotype correlations in the multiple pterygium syndromes. J Med Genet 2012;49:21-26.

10. Ferini-Strambi L, Sansoni V, Combi R. Nocturnal frontal lobe epilepsy and the acetylcholine receptor. Neurologist 2012;18:343-349.

11. Heron SE, Smith KR, Bahlo M, et al. Missense mutations in the sodium-gated potassium channel gene KCNT1 cause severe autosomal dominant nocturnal frontal lobe epilepsy. Nat Genet 2012;44:1188-1190.

12. Hurst R, Rollema H, Bertrand D. Nicotinic acetylcholine receptors: from basic science to therapeutics. Pharmacol Ther 2013;137:22-54

13. Szafranski P, Schaaf CP, Person RE, et al. Structures and molecular mechanisms for common 15q13.3 microduplications involving CHRNA7: benign or pathological? Hum Mutat 2010;31:840-850.

14. Araud T, Graw S, Berger R, et al. The chimeric gene CHRFAM7A, a partial duplication of the CHRNA7 gene, is a dominant negative regulator of a ${ }^{*}$ nAChR function. Biochem Pharmacol 2011;82:904-914

15. Sharp AJ, Mefford HC, Li K, et al. A recurrent 15q13.3 microdeletion syndrome associated with mental retardation and seizures. Nat Genet 2008;40:322-328. 
16. Miller DT, Shen $Y$, Weiss LA, et al. Microdeletion/duplication at 15q13.2q13.3 among individuals with features of autism and other neuropsychiatric disorders. J Med Genet 2009:46:242-248.

17. Ben-Shachar S, Lanpher B, German JR, et al. Microdeletion 15q13.3: a locus with incomplete penetrance for autism, mental retardation, and psychiatric disorders. J Med Genet 2009;46:382-388.

18. van Bon BW, Mefford HC, Menten B, et al. Further delineation of the $15 q 13$ microdeletion and duplication syndromes: a clinical spectrum varying from nonpathogenic to a severe outcome. J Med Genet 2009;46:511-523.

19. Stefansson H, Rujescu D, Cichon S, et al.; GROUP. Large recurrent microdeletions associated with schizophrenia. Nature 2008;455:232-236.

20. International Schizophrenia Consortium. Rare chromosomal deletions and duplications increase risk of schizophrenia. Nature 2008;455:237-241.

21. Helbig I, Mefford HC, Sharp AJ, et al. 15q13.3 microdeletions increase risk of idiopathic generalized epilepsy. Nat Genet 2009;41:160-162.

22. Shinawi M, Schaaf CP, Bhatt SS, et al. A small recurrent deletion within $15 q 13.3$ is associated with a range of neurodevelopmental phenotypes. Nat Genet 2009:41:1269-1271.

23. Cooper GM, Coe BP, Girirajan S, et al. A copy number variation morbidity map of developmental delay. Nat Genet 2011;43:838-846.

24. Endris V, Hackmann K, Neuhann TM, et al. Homozygous loss of CHRNA7 on chromosome $15 q 13.3$ causes severe encephalopathy with seizures and hypotonia. Am J Med Genet A 2010;152A:2908-2911.

25. Liao J, DeWard SJ, Madan-Khetarpal S, Surti U, Hu J. A small homozygous microdeletion of 15q13.3 including the CHRNA7 gene in a girl with a spectrum of severe neurodevelopmental features. Am J Med Genet A 2011;155A:2795-2800.

26. Spielmann M, Reichelt $G$, Hertzberg $C$, et al. Homozygous deletion of chromosome 15q13.3 including CHRNA7 causes severe mental retardation, seizures, muscular hypotonia, and the loss of KLF13 and TRPM1 potentially cause macrocytosis and congenital retinal dysfunction in siblings. Eur J Med Genet 2011;54:e441-e445.

27. Girirajan S, Rosenfeld JA, Coe BP, et al. Phenotypic heterogeneity of genomic disorders and rare copy-number variants. N Eng/ J Med 2012;367:1321-1331.

28. Williams NM, Franke B, Mick E, et al. Genome-wide analysis of copy number variants in attention deficit hyperactivity disorder: the role of rare variants and duplications at 15q13.3. Am J Psychiatry 2012;169:195-204.

29. Jarick I, Volckmar AL, Putter C, et al. Genome-wide analysis of rare copy number variations reveals PARK2 as a candidate gene for attention-deficithyperactivity disorder. Mol Psychiatry 2014;19:115-121.

30. Stergiakouli E, Hamshere M, Holmans P, et al.; deCODE Genetics; Psychiatric GWAS Consortium. Investigating the contribution of common genetic variants to the risk and pathogenesis of ADHD. Am J Psychiatry 2012;169:186-194.

31. Gotti C, Clementi F. Neuronal nicotinic receptors: from structure to pathology. Prog Neurobio/ 2004;74:363-396.

32. Leonard S, Adams C, Breese CR, et al. Nicotinic receptor function in schizophrenia. Schizophr Bull 1996;22:431-445.

33. Freedman R, Olincy A, Ross RG, et al. The genetics of sensory gating deficits in schizophrenia. Curr Psychiatry Rep 2003;5:155-161.

34. Leonard S, Gault J, Hopkins J, et al. Association of promoter variants in the alpha7 nicotinic acetylcholine receptor subunit gene with an inhibitory deficit found in schizophrenia. Arch Gen Psychiatry 2002;59:1085-1096.

35. Citrome L. A review of the pharmacology, efficacy and tolerability of recently approved and upcoming oral antipsychotics: an evidence-based medicine approach. CNS Drugs 2013;27:879-911

36. Coyle JT, Price DL, DeLong MR. Alzheimer's disease: a disorder of cortical cholinergic innervation. Science 1983;219:1184-1190.

37. Court J, Martin-Ruiz C, Piggott M, Spurden D, Griffiths M, Perry E. Nicotinic receptor abnormalities in Alzheimer's disease. Biol Psychiatry 2001;49:175184.

38. Wevers A, Monteggia L, Nowacki S, et al. Expression of nicotinic acetylcholine receptor subunits in the cerebral cortex in Alzheimer's disease: histotopographical correlation with amyloid plaques and hyperphosphorylatedtau protein. Eur J Neurosci 1999;11:2551-2565.

39. Quik M. Smoking, nicotine and Parkinson's disease. Trends Neurosci 2004;27:561-568.

40. Engel AG, Ohno K, Milone M, et al. New mutations in acetylcholine receptor subunit genes reveal heterogeneity in the slow-channel congenital myasthenic syndrome. Hum Mol Genet 1996;5:1217-1227.

41. Croxen R, Newland C, Beeson D, et al. Mutations in different functional domains of the human muscle acetylcholine receptor alpha subunit in patients with the slow-channel congenital myasthenic syndrome. Hum Mol Genet 1997;6:767-774.
42. Sine SM, Ohno K, Bouzat C, et al. Mutation of the acetylcholine receptor alpha subunit causes a slow-channel myasthenic syndrome by enhancing agonist binding affinity. Neuron 1995;15:229-239.

43. Milone M, Wang HL, Ohno K, et al. Slow-channel myasthenic syndrome caused by enhanced activation, desensitization, and agonist binding affinity attributable to mutation in the M2 domain of the acetylcholine receptor alpha subunit. J Neurosci 1997;17:5651-5665.

44. Wang $\mathrm{HL}$, Milone $\mathrm{M}$, Ohno K, et al. Acetylcholine receptor M3 domain: stereochemical and volume contributions to channel gating. Nat Neurosci 1999:2:226-233.

45. Shen XM, Ohno K, Tsujino A, et al. Mutation causing severe myasthenia reveals functional asymmetry of AChR signature cystine loops in agonist binding and gating. J Clin Invest 2003;111:497-505.

46. Masuda A, Shen XM, Ito M, Matsuura T, Engel AG, Ohno K. hnRNP H enhances skipping of a nonfunctional exon P3A in CHRNA1 and a mutation disrupting its binding causes congenital myasthenic syndrome. Hum Mol Genet 2008; 17:4022-4035.

47. Webster R, Brydson M, Croxen R, Newsom-Davis J, Vincent A, Beeson D. Mutation in the AChR ion channel gate underlies a fast channel congenital myasthenic syndrome. Neurology 2004;62:1090-1096.

48. Michalk A, Stricker S, Becker J, et al. Acetylcholine receptor pathway mutations explain various fetal akinesia deformation sequence disorders. Am J Hum Genet 2008;82:464-476.

49. Aridon P, Marini C, Di Resta $C$, et al. Increased sensitivity of the neuronal nicotinic receptor alpha 2 subunit causes familial epilepsy with nocturnal wandering and ictal fear. Am J Hum Genet 2006;79:342-350.

50. Steinlein OK, Mulley JC, Propping P, et al. A missense mutation in the neuronal nicotinic acetylcholine receptor alpha 4 subunit is associated with autosomal dominant nocturnal frontal lobe epilepsy. Nat Genet 1995;11:201-203.

51. Cho YW, Motamedi GK, Laufenberg I, et al. A Korean kindred with autosomal dominant nocturnal frontal lobe epilepsy and mental retardation. Arch Neurol 2003;60:1625-1632.

52. Hirose S, Iwata $\mathrm{H}$, Akiyoshi $\mathrm{H}$, et al. A novel mutation of CHRNA4 responsible for autosomal dominant nocturnal frontal lobe epilepsy. Neurology 1999;53:1749-1753.

53. Gomez CM, Maselli R, Gammack J, et al. A beta-subunit mutation in the acetylcholine receptor channel gate causes severe slow-channel syndrome. Ann Neurol 1996;39:712-723.

54. Quiram PA, Ohno K, Milone M, et al. Mutation causing congenital myasthenia reveals acetylcholine receptor beta/delta subunit interaction essential for assembly. J Clin Invest 1999;104:1403-1410.

55. De Fusco M, Becchetti A, Patrignani A, et al. The nicotinic receptor beta 2 subunit is mutant in nocturnal frontal lobe epilepsy. Nat Genet 2000;26:275-276.

56. Phillips HA, Favre I, Kirkpatrick M, et al. CHRNB2 is the second acetylcholine receptor subunit associated with autosomal dominant nocturnal frontal lobe epilepsy. Am J Hum Genet 2001;68:225-231.

57. Brownlow S, Webster R, Croxen R, et al. Acetylcholine receptor delta subunit mutations underlie a fast-channel myasthenic syndrome and arthrogryposis multiplex congenita. J Clin Invest 2001;108:125-130.

58. Gomez CM, Maselli RA, Vohra BP, et al. Novel delta subunit mutation in slowchannel syndrome causes severe weakness by novel mechanisms. Ann Neurol 2002;51:102-112.

59. Ohno K, Quiram PA, Milone M, et al. Congenital myasthenic syndromes due to heteroallelic nonsense/missense mutations in the acetylcholine receptor epsilon subunit gene: identification and functional characterization of six new mutations. Hum Mol Genet 1997;6:753-766.

60. Sieb JP, Kraner S, Rauch M, Steinlein OK. Immature end-plates and utrophin deficiency in congenital myasthenic syndrome caused by epsilon-AChR subunit truncating mutations. Hum Genet 2000;107:160-164.

61. Müller JS, Stucka R, Neudecker S, et al. An intronic base alteration of the CHRNE gene leading to a congenital myasthenic syndrome. Neurology 2005;65:463-465.

62. Nichols P, Croxen R, Vincent A, et al. Mutation of the acetylcholine receptor epsilon-subunit promoter in congenital myasthenic syndrome. Ann Neurol 1999;45:439-443.

63. Croxen R, Newland C, Betty M, Vincent A, Newsom-Davis J, Beeson D. Novel functional epsilon-subunit polypeptide generated by a single nucleotide deletion in acetylcholine receptor deficiency congenital myasthenic syndrome. Ann Neurol 1999;46:639-647.

64. Abicht A, Stucka R, Karcagi V, et al. A common mutation (epsilon1267delG) in congenital myasthenic patients of Gypsy ethnic origin. Neurology 1999;53:1564-1569. 
65. Morar B, Gresham D, Angelicheva D, et al. Mutation history of the roma/ gypsies. Am J Hum Genet 2004;75:596-609.

66. Richard P, Gaudon K, Haddad H, et al. The CHRNE 1293insG founder mutation is a frequent cause of congenital myasthenia in North Africa. Neurology 2008;71:1967-1972.

67. Ohno K, Hutchinson DO, Milone M, et al. Congenital myasthenic syndrome caused by prolonged acetylcholine receptor channel openings due to a mutation in the M2 domain of the epsilon subunit. Proc Natl Acad Sci USA 1995;92:758-762.

68. Ohno K, Wang HL, Milone M, et al. Congenital myasthenic syndrome caused by decreased agonist binding affinity due to a mutation in the acetylcholine receptor epsilon subunit. Neuron 1996;17:157-170.

69. Wang HL, Ohno K, Milone M, et al. Fundamental gating mechanism of nicotinic receptor channel revealed by mutation causing a congenital myasthenic syndrome. J Gen Physio/ 2000;116:449-462.
70. Shen XM, Brengman JM, Edvardson S, Sine SM, Engel AG. Highly fatal fastchannel syndrome caused by AChR e subunit mutation at the agonist binding site. Neurology 2012;79:449-454.

71. Gomez CM, Gammack JT. A leucine-to-phenylalanine substitution in the acetylcholine receptor ion channel in a family with the slow-channel syndrome. Neurology 1995;45:982-985.

72. Croxen R, Vincent A, Newsom-Davis J, Beeson D. Myasthenia gravis in a woman with congenital AChR deficiency due to epsilon-subunit mutations. Neurology 2002;58:1563-1565

73. Hoffmann K, Muller JS, Stricker S, et al. Escobar syndrome is a prenatal myasthenia caused by disruption of the acetylcholine receptor fetal gamma subunit. Am J Hum Genet 2006;79:303-312.

74. Morgan NV, Brueton LA, Cox P, et al. Mutations in the embryonal subunit of the acetylcholine receptor (CHRNG) cause lethal and Escobar variants of multiple pterygium syndrome. Am J Hum Genet 2006;79:390-395. 